\title{
Lexical and semantic field as reflection of interpenetration and interaction of different types of common polynational language
}

\author{
Yu.S. Dzyubenko \\ Department of Germanic and Romance Philology \\ Volgograd State University \\ Volgograd, Russia \\ Dz_julie@volsu.ru
}

\begin{abstract}
The article is devoted to the study of the lexical and semantic field as a microsystem of multiple lexical units united by common meaning of the word 'education' and reflecting the given conceptual field in the language. Aggregation of the linguistic units by their semantic content is the base of field lexical and semantic modeling. The concept of the field makes it possible to describe the microstructural interactions of the linguistic units. The units of the same language field reflect the objective, conceptual or functional similarities of the phenomena being described; therefore, the field model represents a dialectical connection between linguistic phenomena and the extralinguistic world. The article presents the system-based approach to field modeling of the language system; explores the semantic field of words and their lexical and semantic types; establishes their similarities and differences; identifies the types of semantic field research. Both the similarities and differences were revealed at the denotative and significative levels, which made it possible to identify denotative, significative and denotative-significative divergents. On the one hand, the specific realities, and, on the other hand, the special logical and evaluative understanding of the French, Belgians, Swiss and Canadians are used in these studies as the objects of the names in such countries as France, Belgium, Switzerland and Canada.
\end{abstract}

Keywords-Lexical and semantic field, lexical and semantic types, significative divergents, denotative divergents, intervariant synonymy, intervariant conceptual field.

\section{INTRODUCTION}

The lexical and semantic field (LSF) is not yet completely studied in spite of the fact that there are a large number of studies devoted to this problems. In particular, "there are no strict limits to the application of this term. They often denote different system-forming units of vocabulary, i.e. lexical and semantic groups of words (LSG) and proper semantic fields, which leads not only to the confusion of the most important concepts of lexicology, but also prevents an adequate description of the principles of the system arrangement of the language level' [7].

Let us consider the field as a microsystem of a set of lexical units united by a common meaning - 'formation', and reflecting the given conceptual field in the language. Let us study the arrangement based on the LSF concept where words are combined according to the topic. L.G. Vedenina explains the term 'field' as a generalization that structures linguistic and cultural competence in a specific area of the society. In LSF, lexical units are united by a common content and reflect the conceptual and functional similarity of the indicated phenomena. The lexical and semantic field is singled out by one common seme (it includes the words of one part of speech); the lexical and semantic group is singled out by several common semes. [8]. When LSF is singled out 'two words are considered to be semantically related to each other if there is at least one common component in the interpretation of these words' [5].

According to N.F. Alefirenko, the main advantage of the field model of a language system is the ability to represent the language as a system of systems between which there is an interaction and mutual representation. As a result of this approach, the language appears as a functioning system in which the reordering of the elements and the relations between them takes place [1].

The units of the same language field reflect the objective, conceptual or functional similarities of the phenomena being designated; therefore, the field model represents a dialectic connection between linguistic phenomena and the extralinguistic world [1].

LSF is a reflection of the linguistic world-image, more precisely, of its specific site. The researchers point out that the study of the linguistic world-image should be conducted taking into account both static and dynamic aspects: The first one gives an idea of the linguistic world-image resulted from the accomplished process and the second solves the issue of how the linguistic image of reality is created by means of a particular language' [17]. With the reference to the authors' studies, this implies the analysis of educational vocabulary of the French language of such countries as France, Belgium, Switzerland and Canada recorded in dictionaries and newspapers. Taking into account the second aspect (the dynamic aspect), it makes it possible to consider territorial types of the language, which differ from each other in the evolution rate, deviation nature from the general French standard and the degree of history preservation. 
The unit of the semantic aspect of a language, i.e. the unit cell of its semantic evolution would be the nomination relation. This relation connects the linguistic element (name) and the reality designated by it [4]. The change in the nomination relationship is possible because the denotata constitute a certain system, as a result of which the words denoting the corresponding denotata form lexical and semantic fields.

A thematic group (TG) is a collection of words denoting a specific subject area (N.F. Aleifirenko); words are united here by one typical situation, one theme; common denotation space denoted by them, as well as extralinguistic conditionality of relations, is typical for them; the general identifying seme is not necessary (L.M. Vasiliev). Nouns which are a part of the thematic group are characterized by the relations of hyponymy (gender - type) and quasi-hyponymy (part - whole). The name of the TG (établissements d'enseignement meaning educational institution is a hyperonim) is a generic name of the subject domain; the TG is not considered as a member: hyponyms would be école maternell meaning a kindergarten, collège - meaning a college, lycée - meaning a lyceum, université - meaning a university, etc.

When studying a semantic field of words and their lexical and semantic types, as well as identifying their similarity and difference, the differential components of the meaning would be the semantic components or semes. Seme is implemented as a component of the sememe, which is the simple meaning of a word (lexical and semantic types of a word). Thus, the content of each word meaning (sememe) is represented as a set of elementary meanings (semes). Some semes unite this word with another word, while others differentiate them from each other [4].

The semantic structure of the word meaning consists of an archiseme and differential semes. An archiseme reflects the generic concept, which encompasses all concepts denoted by the words referring to one conceptual field. So, for the words collège meaning college, lycée meaning lyceum, université meaning university, an educational institution is identified as an overall archiseme. With the help of differential semes, the differences of the semantic field units are described. For example, two semes that form the main lexical meaning of the word maternelle namely: école facultative meaning educational institution with optional attendance, école accueillant les enfants de deux à six ans meaning educational institution for children aged two to six years old, act as species, specifiers of the generic concept établissement d'enseignement meaning an educational institution. Due to these differential sememes, the word maternelle as a term of the educational field stands against the other members of the semantic field: maternelle - université (pre-school education higher education), maternelle - collège (optional education compulsory education), etc. Archisemes and differential semes are in hyper-hyponymic relations.

Since the word is identified by two aspects: formal (signifying) and substantive (signified), the word unification in the field can be done basing on both signifying and signified aspects. In this connection, verbal fields based on the unity of lexeme and conceptual fields based on the unity of the sememe are distinguished.

The change in the lexical sign can be caused by the factors related to one of three planes of the semantic triangle: to the expression plan (form), to the content plan (signifier of the linguistic sign) and to the reality plan (denotatum). When comparing lexical nominations, the discrepancies may appear in each of this plan [4].

\section{TYPES OF SEMANTIC STUDY OF FIELDS}

The subject of the investigation is the meanings of a single word, a series of words united by a common morpheme and a group of words united by a common meaning.

Basing on the content, the subject of the study would be the way of expressing an individual referent, a semantic field and a group of referents united by a generality of the lexical expression.

The following types of the semantic study of fields are distinguished:

I. $\mathrm{M}-\mathrm{r}_{1}, \mathrm{r}_{2}, \mathrm{r}_{3}\left(\mathrm{M}\right.$ is a word, $\mathrm{r}_{1}, \mathrm{r}_{2}, \mathrm{r}_{3}$ are a conceptual field).

II. M, X, Y $-\mathrm{r}(\mathrm{M}, \mathrm{X}, \mathrm{Y}$ are a heteromorphic group of words, $r$ is a separate referent).

III. $\mathrm{M}, \mathrm{X}, \mathrm{Y}-\mathrm{r}_{1}, \mathrm{r}_{2}, \mathrm{r}_{3}(\mathrm{M}, \mathrm{X}, \mathrm{Y}$ are a heteromorphic group of words, $r_{1}, r_{2}, r_{3}$ are a conceptual field).

Type I. One word covers a certain field. However, slightly different meaning of the word may lead to some differences in the word type depending on the territory. Denotative divergents are the lexemes which denote such objects (objects, phenomena, creatures, etc.) that have specific attributes of qualitative or functional properties on the territory of France, Belgium, Canada or Switzerland. So, if one studies the lexeme collégien from the territorial point of view, it would mean a college student. However, there is a difference at the denotative level. A college in France, Belgium, Switzerland and Canada would be different educational institutions.

In France, collège is an educational institution that belongs to the first cycle of general secondary education, where all students after a primary school get enrolled without any transfer exam. Collège - établissement du premier cycle du second degré [15].

Collège in Belgium is a private educational institution of complete secondary education (usually Catholic). Collège établissement libre d'enseignement secondaire complet, généralement catholique [9].

The word collège in Canada refers to an institution of general and vocational education between secondary school and the university [12]. Collège d'enseignement général et professionnel ou cégep est un établissement d'enseignement collégial québécois où est offerte une formation technique et pré-universitaire.

In some cantons in Switzerland, the word collège means the second level of secondary education, which in France would be called lycée. Collège - établissement d'enseignement 
secondaire du deuxième cycle qui délivre le certificat de maturité [13].

There are differences as far as it concerns establishment and operation of all these educational institutions. For example, secondary education in Belgium lasts 6 years (from the age of 12 to 17 ) which is currently divided into three cycles of two years each. The first cycle provides basic knowledge; the second and third cycles comprise 3 or 4 types of education, depending on the community (French or Flemish) where the institution is located:

1. Basic education (Enseignement secondaire général ESG)

2. Engineering education (Enseignement secondaire technique - EST)

3. Professional education (Enseignement secondaire professionnel - ESP)

4. Artistic education (Enseignement secondaire artistique - ESA). This type of education exists in Flanders.

It is possible to add up the $7^{\text {th }}$ year of study as a preparation for the higher education after any of these types of training.

Belgian schoolchildren take an exam set up by an educational institution or canton at the end of each year or at the end of the cycle. After completing secondary education, students receive a certificate of complete secondary education 'Certificat d'Enseignement Secondaire Supérieur - CESS'.

In Canada, secondary education differs depending on the province. Most provinces, especially Ontario, have the system of education similar to the American one (4 levels for 4 years). Training in the secondary schools of Canada lasts 5 years (from 12 to 16 years) and consists of two cycles: 1 . three years of training; 2. two years of training [15]. However, this educational institution is called the school (école) and not the college (collège). Canadians would call the establishment the college in case it provides a three-year program of general or vocational training before entering a higher educational institution called cégep (collège d'enseignement général).

The French college training lasts 4 years and is divided into two cycles: the cycle of observation (cycle d'observation) - 6-5 forms or classes, and the orientation cycle (cycle d'orientation) - 4-3 forms or classes [18]. At the end of the observation cycle, some students leave the college and go to the lycée d'enseignement professionnel (LEP) or to other institutions that will provide training in the field of their studies. At the age of 16, a student may leave college or LEP if his/her parents do not have objections to it [18]. After completing secondary education, students receive a certificate Diplôme national du brevet.

Despite the generality of the lexical form of the word collège and the significant form of the 'college', there is a clear discrepancy in the operational nature of the defined educational institutions in different territories: training systems in colleges of French-speaking countries are not the same. The Belgians receive a complete secondary education studying in college; the French receive incomplete education and the Canadians living in Quebec enter the college after receiving secondary education. There is a difference in the age of children.

Thus, the lexeme collège is a denotative divergent, which in different francophone territories has specific attributes of qualitative and functional properties.

Type II. Various lexemes from the territorial types, which correlate with the general referent regardless of their lexical form, are considered. This type of study includes elements of semasiological and onomasiological analysis. Semasiological and onomasiological approaches are inextricably linked and complement each other. Studying one and the same object, such complex study leads to the identification of lexical groups: at the level of concepts (conceptual groups) and at the level of semantic analysis (semantic groups or fields).

In this study, the educational field and, accordingly, the lexical and semantic fields in different national variants of the French language (France, Belgium, Switzerland and Canada) are considered. Subsystems are identified within the LSF Education: the names of educational institutions, the structure of educational institutions (faculties, departments, levels of education), teachers and students, certificates and diplomas, etc. When conducting seme analysis of the components of this lexical field (semasiological approach), the authors get the linguistic structure of the concept (onomasiological approach).

By combining both the semasiological (from the form to meaning of a word) and onomasiological approaches (from the meaning to the forms of its expression), the authors are striving to bridge the gap between sociolinguistics, linguistics and cognitive sciences. Comparison of territorial types or variants helps to identify the common nature and difference in the development trends of the French language.

For example, a group of words lycée (French), athénée (Belgian), gymnase and école secondaire (Canadian) corresponds to one referent (secondary school of the second level of education).

After graduating from college, French students continue their studies at the Lyceum. Lyceums offer general education (philology, economics, natural sciences), technological (medicine, sociology, scientific and industrial technologies) and professional training. Lycée in France represents the second stage of secondary education lasting 3 years (aged 1618) and, at the same time, a transition to higher education. Lycée - établissement qui dispense l'enseignement du second cycle du second degré [16]. There are two types of lyceums: general and vocational. Lyceum students take final exams in accordance with the chosen field of study.

The French lycée corresponds to aténée in Belgium. Athénée is the institution officielle d'enseignement secondaire destinée aux jeunes gens ou mixte, correspondent au lycée en France [2]. Atheneum in Belgium is the official institution of secondary education for boys or co-education for boys and girls. In addition, the word athénée in Belgium and Switzerland has the meaning of a lecture or reading hall. In the Belgian atheneum, the training lasts 4 years and is divided into three cycles. About half of the students in the first and second stages receive general pedagogical training, art education and pass handicraft or technical training; others undergo a general 
training course. About half of the students from the latter group continue to attend the highest level of secondary school, graduation of which gives students the right to enter the university.

At the end of the second cycle, students are practically tied to a specific field, and to change it, they will have to undergo an additional year of reorientation. In the third and final cycle, students finally confirm their choice. The general educational component of their education on this cycle is significantly reduced compared with the profile component.

In Switzerland, the French lyceum corresponds to a gymnase in the cantons of Berne, Friborg and Vaud, the lycée, collège, école could be found in another cantons. Gymnase établissement d'enseignement secondaire supérieur, dont la fréquentation fait suite à celle de l'école secondaire, se termine par les examens de maturité et permet l'accès à l'université [13].

In Switzerland those students who wish to enter the university after the $9^{\text {th }}$ grade continue their study in four-year schools of the gymnasium type (gymnasiums, lyceums, colleges and some others), after which one can get a certificate of secondary education and go to universities and higher polytechnic establishments to continue study without passing exams. Education in the Swiss gymnasiums corresponds to the last years of study at the second stage in the French lyceum.

In Quebec, the second cycle of secondary education is also called école secondaire meaning high school. The second cycle lasts only two years since after the graduation from high school, students continue their study at one of the colleges of Quebec to enter a higher educational institution.

The French and Belgian lexeme lycée differ from each other to some extent. As it was mentioned above, the French lycée is a final stage of secondary education in France. This term has acquired a special semantics in the Belgium language. At present, this is a complete secondary education institution, which is similar to the Belgian college. But the Belgian words lycée and collège are not complete synonyms, i.e. collège, as a rule, is a Catholic educational institution. In France, the lyceum is only a part of secondary education. In this case, changing the meaning of the French word concerns both the significative and denotative parts of the word meaning. The French word concept is wider compared to the Belgian word concept, which means that in the Belgian version of the French language, this word has a wider meaning. In other words, the word lycée in both countries relates to different realities and different concepts.

The presence of denotative and significative divergents shows that the nomination object belongs to a specific cultural environment and that the Belgians have developed a special understanding of the object.

As a result of expanding or narrowing the value, an increase in the number of values in the semantic word structure occurs. An example of a denotative and significative divergent can also serve as a lexeme athénée meaning a lecture or reading hall (Belgian): 1. second level of secondary education; 2. lecture or reading hall. In this case, the Belgian version additionally includes a local value with an additional denotata.

The lexemes which differ from the general French standard by the number of word meanings in France were assigned to the significative divergents:

- enseignement secondaire - the first level of secondary education (Belgian) / high school (general French);

- $\quad$ école secondaire - the first level of secondary education (specific element of French in Switzerland, Canada) / high school (general French);

- lycée - complete secondary education (Belgian) / second level of secondary education (general French).

Thus, the lexemes lycée (French) - athenée (Belgian) gymnase (specific element of French in Switzerland) - école secondaire (Canadian) are incomplete intervariant synonyms. As there are different names, all these lexemes belong to the vocabulary associated with education and have a common significate - 'the second level of secondary education'; however, there are semantic differences between them at the denotative level. The main difference at the level of denotata or reference is the term of study and the age of schoolchildren. The terms of training in the Belgian athenaeum (athénée) and Swiss gymnasium (gymnase) are similar (2 years). However, the Belgians being at the first level of education for 2 years (and the Swiss for 3 years) are transferred to the second level at the age of 14 (the Swiss at the age of 15 respectively). In connection with complex interconnection of denotative, significative and denotative-significative divergents, several cases of incomplete intervariant synonymy were found:

- first level of secondary education: collège (French) enseignement secondaire (Belgian) - école secondaire (Belgian. Canadian);

- $\quad$ second level of secondary education: lycée (French) athénée (Belgian) - gymnase (Belgian) - école secondaire (Canadian).

Type III. In this study, different lexemes are united not only by one referent, but also by a number of referents forming a conceptual field. The word 'diplomas' can be studied as a concept field, which includes several lexical units with different references and significants. As a result of the meaning expansion or narrowing, an increase in the number of meanings in the semantic structure of a common French word occurs. From this point of view, the denotative-significative divergents are singled out: in general, the structure of the meaning of this word, a local meaning with additional denotata or reference is additionally included.

The LSF 'diplomas' in territorial variants of the French language of France, Belgium, Switzerland and Quebec includes 25 lexical units, which describe documents that are issued after graduation. Three lexical and semantic groups have been singled out within the LSF 'diplomas': 1) primary education completion documents (2 lexical units), 2) secondary education completion documents (14 lexical units), 3) higher education completion documents (9 lexical units). As for the preschool education, the names of kindergarten 
completion documents on the studied territories were not found.

After primary school completion in France and Belgium, children receive the certificates: in France - Certificat d'études primaires (CEP), in Belgium - Certificat d'études de base (CEB).

Upon the completion of the first level of secondary education in France, the Diplôme national du brevet $(D N B)$ or Certificat de formation générale $(C F G)$ is issued to graduates. In Belgium, they receive the Diplôme du premier degré and Diplôme du second degré, and in Switzerland it would be the Certificat d'études secondaires. In Quebec, a high school diploma is issued only after the second final level of study.

After graduating from college, French students can take a short course of the second level at the end of which they receive the Certificat d'aptitude professionnelle 'Certificate equal to the diploma of vocational training or Brevet d'enseignement professionnel meaning the certificate of vocational training. They may also choose to go to a lyceum at the end of which they may get Baccalauréat meaning a bachelor degree, Brevet de technicien meaning the certificate of engineering education or Baccalauréat professionnel meaning a bachelor degree in the specific field. The bachelor studies in France last for three years at the lyceum (second, first and final) after which they are entitled to enter a higher educational institution. The secondary school certificate is of three types in three different fields: literature (L), science (S) or economics (ES). The second field also implies rather narrow studies: natural sciences and technologies in the field of service (STT), natural sciences and industrial engineering (STI), science and laboratory technologies (STL) as well as medical and social sciences (SMS). In Belgium and Switzerland, there are analogues to French undergraduate studies; however, they are called in a different way. So, the name of the Belgian certificate of completion of the secondary education (Certificat d'Enseignement Secondaire Supérieur) contains qualifiers that indicate the highest, i.e. the second level of secondary school. In Switzerland, the Certificat de maturité denotes the maturity of a schoolboy or schoolgirl who graduated from high school. However, in Swiss version of the French language, one uses the lexeme baccalauréat with another denotata or reference. In some Swiss cantons, the undergraduate studies or bachelor studies would have a meaning of a final exam passed by students after they graduate from gymnasium (Baccalauréat est un nom donné dans certains cantons à l'examen de maturité) [13]. However, one can see that the examinations passed to get a bachelor degree after secondary school in France and Switzerland are not exactly the same: French schoolchildren pass the exam after the lyceum and Swiss ones take the exam when they graduate from gymnasium. Hence, the denotative meaning of these educational institutions is not the same. It is interesting that in order to get a bachelor degree, French and Swiss schoolchildren take an exam, which in France is called a baccalauréat and in Switzerland - an examen de maturité.

The noun certificat appears in two versions of the French language, namely in Belgian and in Swiss; however, the qualifiers of this lexeme are different. The lexeme baccalauréat in addition to the French version is found in other territorial versions of the French language, but with a different meaning.

At the end of the first cycle of education in higher educational institution in France, the Licence (Bachelor) is issued, in Belgium and Quebec - Baccalauréat, in Switzerland - Baccalauréat universitaire (Bachelor). Belgian bachelor degree is a diploma of either university or non-university education, which is the result of the first three-year training cycle. Baccalauréat en Belgique est le diplôme de l'enseignement supérieur universitaire ou non-universitaire sanctionnant la réussite d'un cycle de trois ans [2]. In Switzerland there is a concept of baccalauréat universitaire, which is also known as bachelor. This is a degree awarded to students in higher educational instutions after three years of the first cycle of training. Baccalauréat universitaire est un grade terminant un premier cycle d'études supérieures d'une durée de 3 ans [13].

After the completion of the second cycle, students of French, Belgian and Swiss universities are awarded Master or Doctorat. A complete coincidence of terminology in the external form of names is observed. In Quebec, the Diplôme d'études supérieures spécialisées or Maîtrise and Doctorat are issued. The external form of the names of the Quebec documents somehow differs from the names of European documents.

However, in addition to the basic degrees awarded to students after each level, there are intermediate documents that exist in some countries. For example, in France after the second year of study at the university, the DEUG - Diplôme d'études universitaires générales is issued, and in Quebec a higher education starts with a two-year college education at the end of which the DEC - Diplôme d'études collégiales is issued.

The first cycle of education is designed for three years in France. Upon the completion of the first two years, an examination has to be taken to get a diploma of higher education. Diplôme d'études universitaires générales - un diplôme intermédiaire de la licence dont les intitulés et les programs ne sont plus fixés nationalement. The diploma of higher education is an intermediate diploma of a licentiate. Names and educational programs are not developed by the State. This document makes it possible to find a good job; for this reason many people do not continue their education. At the end of the third year of the university study, students are issued a Licentiate (state diploma of higher education in France). License - un diplôme national and un grade de l'enseignement supérieur en France. Depuis la réforme LMD (licence, master, doctorat), elle correspond généralement à trois années d'études.

The second cycle of education may last from two to five years. It is aimed at in-depth study of the chosen field of training and is accompanied by independent research activities, which should be identified before entering the program of education. Those who have successfully passed this stage are awarded a master degree (Master). Master - un diplôme - généralement universitaire - obtenu après 2 ans d'études après la licence. After another two or three years, a 
doctorate degree can be awarded to a student of French university in case one has acuired up to 180 credits and has completed a research thesis (Doctorat). Doctorat - un grade national dont la réglementation est fixée par arrêté ministériel.

In Belgium, Switzerland and Quebec, the first cycle of education in higher educational institution ends up with the undergraduate studies (Baccalauréat). Despite the similarity in the external form of the name, there are some discrepancies at the denotative level. However, there are some similarities since the accounting of the academic load of students in different countries is based on one and the same system, i.e. the system of transfer and accumulation of credits: one year is 60 credits and one credit amounts to 25-30 hours of academic load. In other words, to obtain a bachelor degree in Belgium, Switzerland and Quebec, one needs to get 180 credits, which is equal to three years of study.

The Master degree or Doctor of Science degree is issued at the end of the second cycle of education in those countries that were studied. The denotative meaning of the lexeme master in the territorial variants of the French language is not the same. For example, in France the term master means one of the university's degrees and a diploma issued after obtaining a degree of a licentiate ( 2 years of study). Master - un grade universitaire et un diplôme préparé en deux années d'études après la licence. Since the time when the Bologna process was initiated, the master degree has been considered as a university and non-university diploma, which can be obtained after a two-year cycle of studies in a higher educational institution in Belgium. Master remplace la license, et est obtenu après un cycle de 2 ans (parfois 1 an) d'étude consécutif au baccalauréat (bachelor) et est délivré par les Universités ou les Hautes Ecoles. The term master has a meaning of a diploma of the second cycle of university education in Switzerland. Master - un diplôme de l'enseignement supérieur universitaire de Second cycle. In Quebec, the term master is missing, but the lexeme maîtrise is used instead. Maîtrise - un diplôme de spécialisation professionnelle ou de recherche. To obtain a master degree in Quebec, one needs to study three years after receiving a bachelor degree.

\section{CONCLUSION}

Thus, some discrepancies may be observed at the denotative level. Despite the fact that a master degree in all four territories is a diploma of the second cycle of education in a higher educational institution, the terms of study are different; therefore, the amount of credits is also different.

In this lexical and semantic field, the seme 'diploma' is used as a core. It is broken up into three interdependent and opposing groups. Taking into account the variability of the French language, 25 lexical units form an intervariant conceptual field.
The presence of denotative-significative divergents indicates the belonging of the nomination object to a specific cultural environment, as well as a special understanding of the object that has developed among the French, Belgians, Swiss or Quebecers. Due to the denotative-significative interweaving, a variability of lexical and semantic field is observed.

\section{References}

[1] N.F. Alefirenko, Modern science issues about the language. Moscow: Nauka, 2005, pp.82-84.

[2] W. Bal, A. Doppagne, A. Goosse, "Belgicismes, Inventaire des particularités lexicales du français en belgique". $1^{\text {re }}$ edition, $2^{\mathrm{e}}$ tirage. Gembloux: Nouvelle Imprimerie Duclot, 1994, p.143.

[3] W. Besch, "Various written and spoken forms - on the discussion of national variants of the german standard language". German life and letters. vol. 43 (2), pp. 91-102, 1990.

[4] M.A. Borodina, V.G. Gak, To the typology and methodology of historical and semantic research. L .: Nauka, 1979, pp. 231. (in Russian).

[5] L.V. Bystrova, N.D. Kapatruk, V.V. Levitsky, On the question of the principles and methods for separating lexical and semantic groups of words, Philological Sciences, No. 6, pp. 75-78, 1980.

[6] Yu. S. Dzyubenko, Variability of lexical and semantic fields in territorial variants of the French language, Bulletin of Volgograd State University, Series 2, vol. 2, No.1-13, pp. 240-244. 2011.

[7] E.I. Dibrova, N.Yu. Donchenko, Poetic structures of antonymy. Moscow: S. Print, 2000, p. 136.

[8] France. Dictonary for linguistics and culture study. 7000 units, Ed. L.G. Vedenina. M .: Interdialect + / AMT; 1997, p. 1028.

[9] J. Hanse, A. Doppagne, H. Bourgeois-Gielen, Chasse aux belgicismes. Bruxelles: Académie française, 1987, $167 \mathrm{p}$.

[10] J. Hanse, A. Doppagne, H. Bourgeois-Gielen, Nouvelle chasse aux belgicismes, Bruxelles: Académie française, 1995, $145 \mathrm{p}$.

[11] F. Hempelmann Christian, Elisa Gironzetti, An interlingual study of the lexical and semantic field LAUGH in Ken Kesey's One Flew over the Cuckoo's Nest, Journal of literary semantics, vol. 44 (2), pp. 141-167, 2015.

[12] V.T. Klokov, Dictionary of French outside France. Saratov: Sarat Publishing House. University, 2000, p. 145.

[13] P. Knecht, A. Thibault, Dictionnaire suisse romand: Particularités lexicales du français contemporain (DSR", Genève: Zoe, 1999, 854 p.

[14] M.I. Kozlov, A.D. Koshelev, One method of a semantic description of the language sign. 1. Significance of a sign and semantic tradition, Research data: series 2 - information processes and systems, vol. 5, pp. 27-31, 1982.

[15] F. Landry, Structure de l'enseignement: Suisse romande et Tessin : Belgique, France, Luxembourg et Québec : année scolaire 2006-2007. [Digital resource]. Digital data - Neuchâtel : Institut de recherche et de documentation pédagogique (IRDP), 2005-2010, Access at: http://www.irdp.ch/.

[16] Le Robert micro: dictionnaire de la langue française, réd. Alain Rey. Paris Dictionnaires Le Robert, 1997, 1506 p.

[17] L. Meney, Dictionnaire québécois-français: pour mieux se comprendre entre francophones. Montréal : Guérin - Canada Edition, 1999, p.1884.

[18] V.P. Sviridonova, La France $=$ France: A Study guide for regional studies. Volgograd: Volgograd State University Press, 2004, pp. 49-50.

[19] V.N. Teliya, Types of language values. The associated meaning of word in the language. Moscow: Nauka, 1981, p. 174. 